\title{
Pengaruh Pelayanan Prima terhadap Kepuasan Pasien Rawat Jalan RSUD Labuang Baji Makassar
}

\section{The Effect of Implementation of Excellent Service on The Satisfaction of Outpatients at The Labuang Baji Hospital, Makassar}

\author{
Reski Dewi Pratiwi ${ }^{1}$, Ryryn Suryaman Prana Putra ${ }^{2}$ \\ ${ }^{12}$ Program Studi Administrasi Rumah Sakit, STIKES Pelamonia Kesdam VII \\ Wirabuana, Makassar \\ (qkidewi@gmail.com, uyaputra17@gmail.com )
}

\begin{abstract}
ABSTRAK
Jumlah kunjungan rawat jalan di RSUD Labuang Baji Makassar menurun dari tahun 2017 sebanyak 47.773 pasien menjadi 45.591 pasien dimana penurunan jumlah kunjungan pasien rawat jalan ini diindikasikan memiliki keterkaitan dengan pelayanan prima yang diberikan rumah sakit. Jenis penelitian yang digunakan adalah penelitian kuantitatif dengan menggunakan desain cross sectional study. Penelitian ini dilaksanakan di ruang rawat jalan RSUD Labuang Baji Makassar. Jumlah sampel sebanyak 397 pasien rawat jalan. Pengambilan data dilakukan dengan menggunakan alat bantu kuesioner. Data dianalisis dengan menggunakan uji chi square pada $\alpha<5 \%$. Hasil penelitian diperoleh bahwa terdapat pengaruh pelayanan prima dari variabel Sikap (Attitude) dengan nilai $\mathrm{p}=0,007$, Perhatian (Attention) dengan nilai $\mathrm{p}=0,001$, Tindakan (Action) dengan nilai $\mathrm{p}=0,003$, Kemampuan (Ability) dengan nilai $\mathrm{p}=0,001$, Penampilan (Appearance) dengan nilai $\mathrm{p}=0,000$, dan Tanggung Jawab (Accountability) dengan nilai $\mathrm{p}=0,000$ terhadap kepuasan pasien rawat jalan di RSUD Labuang Baji Makassar. Semakin baik Sikap (Attitude), Tindakan (Action), Kemampuan (Ability), Penampilan (Appearance), Tanggung Jawab (Accountability) petugas maka akan semakin meningkatkan kepuasan pasien rawat jalan RSUD Labuang Baji Makassar, serta begitu pula sebaliknya. Dapat disimpulkan bahwa Sikap (Attitude), Tindakan (Action), Kemampuan (Ability), Penampilan (Appearance), Tanggung Jawab (Accountability) berpengaruh secara signifikan terhadap kepuasan pasien rawat jalan di RSUD Labuang Baji Makassar.
\end{abstract}

Kata Kunci: Pelayanan prima, kepuasan, rawat jalan

\section{ABSTRACT}

The number of outpatient visits at Labuang Baji Hospital, Makassar decreased from 2017 as many as 47.773 patients to 45.591 patients, this decrease indicated have a relationship with the excellent service provided by hospital. The type of this research is a quantitative study using a cross sectional study design. This research was conducted in the outpatient room of the Labuang Baji Hospital, Makassar. The total sample was 397 outpatients. Data were collected using a questionnaire. Data were analyzed using the chi square test at $\alpha<5 \%$. The results showed that there was an effect of excellent service from the Attitude variable with $p=0.007$, Attention with $p=0.001$, Action with $p=0.003$, Ability with $p=0.001$, Appearance with a value of $p=0,000$, and Accountability with $p=0,000$ on outpatient satisfaction at Labuang Baji Hospital, Makassar. When conditions of services are better on the Attitude variable, Action, Ability, Appearance, Accountability of the officer, it will make increase the satisfaction of outpatients in Labuang Baji Hospital, Makassar. and vice versa. It can be concluded that Attitude, Action, Ability, Appearance, Accountability have a significant effect on outpatient's satisfaction at Labuang Baji Hospital, Makassar.

Keywords: Excellent service, satisfaction, outpatient 


\section{PENDAHULUAN}

Pelayanan prima adalah perbuatan atau tindakan yang memberikan kepada pelanggan apa (yang lebih daripada) yang memang diharapkan pada saat mereka membutuhkan dengan cara yang diinginkan dan lebih baik daripada penawaran sejenis lainnya (Rivai dkk, 2019). Endarini (2001) dalam Hadjam (2001) mendefinisikan pelayanan prima dalam konteks pelayanan rumah sakit berarti pelayanan yang diberikan kepada pasien yang berdasarkan standar kualitas untuk memenuhi kebutuhan dan keinginan pasien sehingga pasien dapat memperoleh kepuasan yang akhirnya dapat meningkatkan kepercayaannya kepada rumah sakit.

Endang menyatakan bahwa kepuasan pasien merupakan evaluasi atau penilaian setelah memakai suatu pelayanan, bahwa pelayanan yang dipilih setidak-tidaknya memenuhi atau melebihi harapan (Mamik, 2010). Parasuraman (2001) menjelaskan bahwa untuk mengetahui gambaran tingkat kepuasan pelanggan (pasien), dapat dilakukan dengan pendekatan kualitas pelayanan atau Service Quality yang diukur dengan menggunakan indikator Bukti Fisik (Tangibles), Kehandalan (Reliability), Ketanggapan (Responsiveness), Jaminan (Assurance), dan Empati (Empathy) (Nursalam, 2015). Kepuasan pasien merupakan salah satu indikator kualitas pelayanan yang kita berikan dan kepuasan pasien adalah suatu modal untuk mendapatkan pasien lebih banyak lagi dan untuk mendapatkan pasien yang loyal (Nursalam, 2014). Sehingga ketika pelayanan yang diberikan kepada pasien di rumah sakit memenuhi harapan bahkan melebihi harapan pasien yang disebut dengan pelayanan prima, maka memberikan kepuasan kepada pasien. Pasien yang puas memudahkan proses penyembuhan pada pasien sehingga tujuan pelayanan prima untuk dapat memberikan penyembuhan dapat tercapai.

Pengukuran kepuasan pada pasien sangat penting dilakukan untuk memberikan evaluasi terhadap pelayanan yang diberikan oleh rumah sakit. Penelitian kepuasan pasien di rumah sakit yang ada di Inggris menemukan bahwa kepuasan pasien terhadap perawatan rumah sakit kurang baik karena pasien merasa tidak tersedianya cukup perawat ketika berada di rumah sakit sehingga penelitian menyarankan untuk menambah jumlah perawat bersertifikat di rumah sakit untuk meningkatkan kepuasan pasien (Aiken et al., 2018). Penelitian di Rumah Sakit Dhulikhel, Nepal menemukan bahwa pasien sangat puas dengan pelayanan fisioterapi sehingga penilaian kepuasan adalah program yang harus dilaksanakan secara berkelanjutan untuk mengetahui dan meningkatkan pelayanan yang diberikan rumah sakit (Shakya \& Shakya, 2019). Penelitian yang dilakukan di India 
Reski Dewi Pratiwi, Ryryn Suryaman Prana Putra : Pengaruh Pelayanan Prima terhadap ...

menemukan bahwa di sektor kesehatan publik seperti di rumah sakit pemerintah faktor yang paling mempengaruhi kepuasan pasien adalah empati dan jaminan (Ahmed \& Ilyas, 2016).

Pasien yang merasa puas terhadap pelayanan yang diberikan dapat membuat pengobatan pasien berjalan dengan lancar tanpa hambatan dan pasien dapat menjadi pelanggan setia di rumah sakit tersebut. Tetapi sebaliknya jika pasien menilai pelayanan kepada dirinya buruk maka pasien merasa tidak puas dan membuat proses pengobatan menjadi terhambat dan pasien bisa saja akan berfikir untuk tidak datang lagi ke rumah sakit tersebut karena telah mengetahui bagaimana kondisi pelayanannya. Penelitian yang dilakukan di RSUD Bhakti Dharma Husada Kota Surabaya menemukan bahwa kepuasan pasien dinilai pada kategori sangat puas dan mendapatkan korelasi bahwa semakin tinggi mutu pelayanan maka tinggi kepuasan pasien (Nurcahyati \& Setiawan, 2017). Penelitian lain yang dilakukan di Rumah Sakit Jemursari Surabaya menemukan bahwa pasien yang cukup puas masih di bawah $80 \%$ sehingga perlu adanya perbaikan (Wijaya \& Adriansyah, 2020).

RSUD Labuang Baji Makassar adalah rumah sakit di bawah Pemerintah Provinsi Sulawesi Selatan yang telah menerima Sertifikat Akreditasi Rumah Sakit dari Komisi Akreditasi Rumah Sakit (KARS) dengan predikat lulus akreditasi bintang 2 dasar. Berdasarkan data dari RSUD Labuang Baji Makassar diperoleh informasi bahwa jumlah kunjungan rawat jalan di RSUD Labuang Baji Makassar menurun dari tahun 2017 sebanyak 47.773 pasien menjadi 45.591 pasien pada tahun 2018 atau terjadi penurunan sebesar 4,57\% (RSUD Labuang Baji Makassar, 2019). Terjadi penurunan jumlah kunjungan pasien rawat jalan khususnya di tahun 2018. Penurunan jumlah kunjungan pasien rawat jalan ini dapat mengindikasikan terdapat sebuah penyebab yang dapat dikaji keterkaitannya dengan pelayanan prima yang diberikan rumah sakit kepada pasien. Berdasarkan latar belakang tersebut dan masalah turunnya jumlah kunjungan rawat jalan di RSUD Labuang Baji Makassar maka peneliti memilih untuk melakukan penelitian untuk mengetahui pengaruh penerapan pelayanan prima pada variabel Sikap (Attitude), Perhatian (Attention), Tindakan (Action), Kemampuan (Ability), Penampilan (Appearance), dan Tanggung iawab (Accountability) terhadap kepuasan pasien rawat jalan yang diukur dengan variable Bukti Fisik (Tangibles), Kehandalan (Reliability), Ketanggapan (Responsiveness), Jaminan (Assurance), dan Empati (Empathy) di RSUD Labuang Baji Makassar. Penelitian ini bertujuan untuk menganalisis pengaruh penerapan pelayanan prima terhadap kepuasan pasien rawat jalan di RSUD Labuang Baji Makassar. 


\section{METODE}

Jenis penelitian yang digunakan adalah penelitian kuantitatif dengan menggunakan desain cross sectional study. Penelitian ini dilaksanakan di ruang rawat jalan RSUD Labuang Baji Makassar dari Bulan Juli sampai September 2020. Populasi dalam penelitian sebanyak 43.853 pasien rawat jalan RSUD Labuang Baji Makassar (RSUD Labuang Baji Makassar, 2019). Dengan menggunakan rumus Slovin maka diperoleh jumlah sampel sebanyak 397 pasien dimana pengambilan sampel menggunakan teknik accidental sampling. Kriteria inklusi sampel adalah pasien rawat jalan di RSUD Labuang Baji Makassar, berusia di atas 17 tahun, mampu berkomunikasi dengan baik, serta bersedia menjadi responden penelitian. Sedangkan kriteria ekslusi sampel adalah bukan pasien rawat jalan di RSUD Labuang Baji Makassar atau pasien rawat inap, berusia di bawah 17 tahun, tidak mampu berkomunikasi dengan baik, serta tidak bersedia menjadi responden penelitian. Data yang dikumpulkan menggunakan instrumen penelitian dalam bentuk kuesioner pelayanan prima dan kepuasan pasien. Hasil uji validitas pada kuesioner adalah seluruh item pertanyaan memiliki status valid, karena nilai $r_{\text {hitung }}$ (Corrected Item-Total Correlation) $>r_{\text {tabel }}$, serta seluruh variabel memiliki nilai $\mathrm{r}_{\text {alpha }}$ (Cronbach's Alpha) lebih besar dari 0,600 yang berarti tujuh variabel reliable (memenuhi persyaratan) atau terpercaya sebagai alat pengumpul data dalam penelitian. Data dianalisis dengan menggunakan aplikasi SPSS secara univariat dan untuk analisis bivariat menggunakan uji chi square pada $\alpha<5 \%$.

\section{HASIL}

Karakteristik responden dalam penelitian ini dilihat berdasarkan kategori jenis kelamin, usia, asal daerah domisili, status pernikahan, pendidikan terakhir, pekerjaan, poliklinik yang didatangi.

Tabel 1. Distribusi Responden Berdasarkan Jenis Kelamin, Usia, Domisili, dan Status Pernikahan

\begin{tabular}{|c|c|c|}
\hline Karakteristik Responden & Frekuensi & Persentase \\
\hline \multicolumn{3}{|l|}{ Jenis Kelamin } \\
\hline Laki-Laki & 142 & 35,8 \\
\hline Perempuan & 255 & 64,2 \\
\hline \multicolumn{3}{|l|}{ Usia } \\
\hline 17-25 tahun & 73 & 18,4 \\
\hline 26-35 tahun & 100 & 25,2 \\
\hline 36-45 tahun & 91 & 22,9 \\
\hline 46-55 tahun & 62 & 15,6 \\
\hline 56-65 tahun & 52 & 13,1 \\
\hline$>65$ tahun & 19 & 4,8 \\
\hline \multicolumn{3}{|l|}{ Domisili } \\
\hline Bantaeng & 1 & 0,3 \\
\hline
\end{tabular}


Reski Dewi Pratiwi, Ryryn Suryaman Prana Putra : Pengaruh Pelayanan Prima terhadap ...

\begin{tabular}{lcc}
\hline Karakteristik Responden & Frekuensi & Persentase \\
\hline Belopa & 1 & 0,3 \\
Bone & 1 & 0,3 \\
Bulukumba & 1 & 0,3 \\
Gowa & 73 & 18,4 \\
Jeneponto & 13 & 3,3 \\
Makassar & 279 & 70,3 \\
Maros & 4 & 1,0 \\
Soppeng & 1 & 0,3 \\
Takalar & 23 & 5,8 \\
Status Pernikahan & & \\
Belum Menikah & 87 & 21,9 \\
Sudah Menikah & 299 & 75,3 \\
Duda & 3 & 0,8 \\
Janda & 8 & 2,0 \\
Total & 397 & 100,0 \\
\hline
\end{tabular}

Berdasarkan Tabel 1 diperoleh informasi bahwa sebagian besar responden berjenis kelamin perempuan yakni sebanyak 255 orang $(64,2 \%)$ dan sisanya berjenis kelamin laki-laki yakni sebanyak 142 orang (35,8\%). Sebagian besar responden berusia antara 26-35 tahun yakni sebanyak 100 orang (25,2\%) dan paling sedikit berusia di atas 65 tahun yakni sebanyak 19 orang (4,8\%). Sebagian besar responden berasal dari daerah Makassar yakni sebanyak 279 orang (70,3\%) dan paling sedikit berasal dari Bantaeng, Belopa, Bone, Bulukumba, dan Soppeng yakni masing-masing sebanyak 1 orang $(0,3 \%)$. Sebagian besar responden sudah menikah yakni sebanyak 299 orang (75,3\%) dan paling sedikit duda yakni sebanyak 3 orang $(0,8 \%)$.

Tabel 2. Distribusi Responden Berdasarkan Pendidikan Terakhir, Pekerjaan, dan Poliklinik yang Dikunjungi

\begin{tabular}{lcc}
\hline Karakteristik Responden & Frekuensi & Persentase \\
\hline Pendidikan Terakhir & & \\
Tamat Diploma & 47 & 11,8 \\
Tamat Magister & 8 & 2,0 \\
Tamat Sarjana & 84 & 21,2 \\
Tamat SD & 7 & 1,8 \\
Tamat SMA & 212 & 53,4 \\
Tamat SMP & 36 & 9,1 \\
Tidak Sekolah & 3 & 0,8 \\
Pekerjaan & 26 & \\
Buruh & 78 & 6,5 \\
Karyawan Swasta & 7 & 19,6 \\
Pegawai BUMN & 52 & 1,8 \\
Pegawai Negeri Sipil & 28 & 13,1 \\
Pelajar & 12 & 7,1 \\
Petani & 141 & 3,0 \\
Tidak Bekerja & 53 & 35,5 \\
Wirausaha & & 13,4 \\
\hline
\end{tabular}




\begin{tabular}{lcc}
\hline Karakteristik Responden & Frekuensi & Persentase \\
\hline Poliklinik yang Dikunjungi & 1 & \\
MCU & 3 & 0,3 \\
Poli Neonatal & 44 & 0,8 \\
Poli Anak & 29 & 11,1 \\
Poli Bedah & 5 & 7,3 \\
Poli Geriatri & 28 & 1,3 \\
Poli Gigi dan Mulut & 11 & 7,1 \\
Poli Jiwa & 13 & 2,8 \\
Poli Kandungan & 15 & 3,3 \\
Poli Kardiologi & 20 & 3,8 \\
Poli Kulit dan Kelamin & 29 & 5,0 \\
Poli Mata & 1 & 7,3 \\
Poli Ortopedi & 2 & 0,3 \\
Poli Paru & 66 & 0,5 \\
Poli Penyakit Dalam & 6 & 16,6 \\
Poli Penyakit Infeksi & 24 & 1,5 \\
Poli Psikiatri & 55 & 6,0 \\
Poli Saraf & 40 & 13,9 \\
Poli THT & 5 & 10,1 \\
Poli VCT & 397 & 1,3 \\
Total & & 100,0 \\
\hline
\end{tabular}

Berdasarkan tabel 2 diperoleh informasi bahwa sebagian besar responden Tamatan SMA yakni sebanyak 212 orang (53,4\%) dan paling sedikit Tidak Sekolah yakni sebanyak 3 orang $(0,8 \%)$. Sebagian besar responden tidak bekerja yakni sebanyak 141 orang (35,5\%) dan paling sedikit bekerja sebagai Pegawai BUMN yakni sebanyak 7 orang (1,8\%). sebagian besar responden mengunjungi Poli Penyakit Dalam yakni sebanyak 66 orang $(16,6 \%)$ dan paling sedikit mengunjungi MCU dan Poli Ortopedi yakni masing-masing sebanyak 1 orang (0,3\%). Berikut hasil univariat penelitian ini.

Tabel 3. Hasil Analisis Univariat Variabel Kepuasan dan Dimensi Pelayanan Prima

\begin{tabular}{lcccc}
\hline \multirow{2}{*}{ Dimensi Variabel } & \multicolumn{4}{c}{ Pelayanan prima atau Kepuasan } \\
\cline { 2 - 5 } & \multicolumn{3}{c}{ Baik } & \multicolumn{2}{c}{ Kurang Baik } \\
\cline { 2 - 5 } & Frekuensi & Persentase & Frekuensi & Persentase \\
\hline Kepuasan & 380 & 95,7 & 17 & 4,3 \\
Sikap (Attitude) & 377 & 95,0 & 20 & 5,0 \\
Perhatian (Attention) & 386 & 97,2 & 11 & 2,8 \\
Tindakan (Action) & 313 & 78,8 & 84 & 21,2 \\
Kemampuan (Ability) & 385 & 97,0 & 12 & 3,0 \\
Penampilan (Appearance) & 382 & 96,2 & 15 & 3,8 \\
Tanggung Jawab & 375 & 94,5 & 22 & 5,5 \\
(Accountability) & & & & \\
\hline
\end{tabular}

Berdasarkan tabel 3 diperoleh informasi bahwa sebagian besar responden menilai Sikap (Attitude) baik yakni sebanyak 377 orang (95,0\%), sebagian besar responden 
Reski Dewi Pratiwi, Ryryn Suryaman Prana Putra : Pengaruh Pelayanan Prima terhadap ...

menilai Perhatian (Attention) baik yakni sebanyak 386 orang (97,2\%), sebagian besar responden menilai Tindakan (Action) baik yakni sebanyak 313 orang (78,8\%), sebagian besar responden menilai Kemampuan (Ability) baik yakni sebanyak 385 orang (97,0\%), sebagian besar responden menilai Penampilan (Appearance) baik yakni sebanyak 382 orang (96,2\%), sebagian besar responden menilai Tanggung Jawab (Accountability) baik yakni sebanyak 375 orang (94,5\%), dan sebagian besar responden merasa puas dengan pelayanan prima di rawat jalan yakni sebanyak 380 orang $(95,7 \%)$. Analisis bivariat bertujuan untuk mengetahui pengaruh variabel independen yakni variabel Sikap (Attitude), Perhatian (Attention), Tindakan (Action), Kemampuan (Ability), Penampilan (Appearance), dan Tanggung Jawab (Accountability) sebagai dimensi dari variabel independen pelayanan prima terhadap variabel dependen Kepuasan dengan menggunakan uji chi square. Berikut hasil dari analisis bivariat variabel tersebut.

Tabel 4. Hasil Uji Bivariat Pengaruh antara Dimensi Pelayanan Prima terhadap Kepuasan Pasien Rawat Jalan di RSUD Labuang Baji Makassar

\begin{tabular}{|c|c|c|c|c|c|c|c|c|}
\hline \multirow{3}{*}{$\begin{array}{c}\text { Dimensi Pelayanan } \\
\text { Prima }\end{array}$} & \multicolumn{4}{|c|}{ Kepuasan } & \multirow{3}{*}{$\mathbf{N}$} & \multirow{3}{*}{$\%$} & \multirow{3}{*}{$\mathbf{r}$} & \multirow{3}{*}{$\boldsymbol{P}$} \\
\hline & \multicolumn{2}{|c|}{ Puas } & \multicolumn{2}{|c|}{ Kurang Puas } & & & & \\
\hline & $\mathbf{n}$ & $\%$ & $\mathbf{n}$ & $\%$ & & & & \\
\hline \multicolumn{8}{|l|}{ Sikap (Attitude) } & \multirow{4}{*}{0,007} \\
\hline Baik & 364 & 96,6 & 13 & 3,4 & 377 & 100,0 & \multirow{3}{*}{0,554} & \\
\hline Kurang Baik & 16 & 80,0 & 4 & 20,0 & 20 & 100,0 & & \\
\hline Total & 380 & 95,7 & 17 & 4,3 & 397 & 100,0 & & \\
\hline \multicolumn{9}{|l|}{ Perhatian (Attention) } \\
\hline Baik & 373 & 96,6 & 13 & 3,4 & 386 & 100,0 & \multirow{3}{*}{0,605} & \multirow{3}{*}{0,001} \\
\hline Kurang Baik & 7 & 63,6 & 4 & 36,4 & 11 & 100,0 & & \\
\hline Total & 380 & 95,7 & 17 & 4,3 & 397 & 100,0 & & \\
\hline \multicolumn{9}{|l|}{ Tindakan (Action) } \\
\hline Baik & 305 & 97,4 & 8 & 2,6 & 313 & 100,0 & \multirow{3}{*}{0,577} & \multirow{3}{*}{0,003} \\
\hline Kurang Baik & 75 & 89,3 & 9 & 10,7 & 84 & 100,0 & & \\
\hline Total & 380 & 95,7 & 17 & 4,3 & 397 & 100,0 & & \\
\hline \multicolumn{9}{|l|}{ Kemampuan (Ability) } \\
\hline Baik & 372 & 96,6 & 13 & 3,4 & 385 & 100,0 & \multirow{3}{*}{0,595} & \multirow{3}{*}{0,001} \\
\hline Kurang Baik & 8 & 66,7 & 4 & 33,3 & 12 & 100,0 & & \\
\hline Total & 380 & 95,7 & 17 & 4,3 & 397 & 100,0 & & \\
\hline \multicolumn{9}{|c|}{ Penampilan (Appearance) } \\
\hline Baik & 371 & 97,1 & 11 & 2,9 & 382 & 100,0 & \multirow{3}{*}{0,624} & \multirow{3}{*}{0,000} \\
\hline Kurang Baik & 9 & 60,0 & 6 & 40,0 & 15 & 100,0 & & \\
\hline Total & 380 & 95,7 & 17 & 4,3 & 397 & 100,0 & & \\
\hline \multicolumn{9}{|c|}{ Tanggung Jawab (Accountability) } \\
\hline Baik & 366 & 97,6 & 9 & 2,4 & 375 & 100,0 & \multirow{3}{*}{0,673} & \multirow{3}{*}{0,000} \\
\hline Kurang Baik & 14 & 63,6 & 8 & 36,4 & 22 & 100,0 & & \\
\hline Total & 380 & 95,7 & 17 & 4,3 & 397 & 100,0 & & \\
\hline
\end{tabular}

Berdasarkan Tabel 4 diperoleh informasi bahwa dari 377 responden yang menilai Sikap (Attitude) baik, sebagian besar merasa puas dengan pelayanan prima di rawat jalan RSUD Labuang Baji Makassar yakni sebanyak 364 orang (96,6\%). Dari 20 responden 
yang menilai Sikap (Attitude) kurang baik, sebagian besar merasa puas dengan pelayanan prima di rawat jalan RSUD Labuang Baji Makassar yakni sebanyak 16 orang (80,0\%). Berdasarkan uji chi square diperoleh nilai $P$ sebesar 0,007 yang lebih kecil dari nilai $\alpha=$ 0,05 sehingga Ho ditolak dan Ha diteriima yang artinya Sikap (Attitude) berpengaruh terhadap kepuasan pasien rawat jalan di RSUD Labuang Baji Makassar. Berdasarkan nilai $\mathrm{r}$ hitung diperoleh nilai 0,554 > r tabel 0,098 yang artinya terdapat hubungan yang cukup kuat dan positif antara Sikap (Attitude) terhadap kepuasan pasien. Dapat dijelaskan bahwa semakin baik Sikap (Attitude) maka semakin tinggi kepuasan pasien rawat jalan di RSUD Labuang Baji Makassar.

Berdasarkan tabel 8 diperoleh informasi bahwa dari 386 responden yang menilai Perhatian (Attention) baik, sebagian besar merasa puas dengan pelayanan prima di rawat jalan RSUD Labuang Baji Makassar yakni sebanyak 373 orang (96,6\%). Dari 11 responden yang menilai Perhatian (Attention) kurang baik, sebagian besar merasa puas dengan pelayanan prima di rawat jalan RSUD Labuang Baji Makassar yakni sebanyak 7 orang (63,6\%). Berdasarkan uji chi square diperoleh nilai $P$ sebesar 0,001 yang lebih kecil dari nilai $\alpha=0,05$ sehingga Ho ditolak dan Ha diteriima yang artinya Perhatian (Attention) berpengaruh terhadap kepuasan pasien rawat jalan di RSUD Labuang Baji Makassar. Berdasarkan nilai $\mathrm{r}$ hitung diperoleh nilai 0,605 > r tabel 0,098 yang artinya terdapat hubungan yang kuat dan positif antara Perhatian (Attention) terhadap kepuasan pasien. Dapat dijelaskan bahwa semakin baik Perhatian (Attention) maka semakin tinggi kepuasan pasien rawat jalan di RSUD Labuang Baji Makassar.

Berdasarkan tabel 8 diperoleh informasi bahwa dari 313 responden yang menilai Tindakan (Action) baik, sebagian besar merasa puas dengan pelayanan prima di rawat jalan RSUD Labuang Baji Makassar yakni sebanyak 305 orang (97,4\%). Dari 84 responden yang menilai Tindakan (Action) kurang baik, sebagian besar merasa puas dengan pelayanan prima di rawat jalan RSUD Labuang Baji Makassar yakni sebanyak 75 orang (89,3\%). Berdasarkan uji chi square diperoleh nilai $P$ sebesar 0,003 yang lebih kecil dari nilai $\alpha=0,05$ sehingga Ho ditolak dan Ha diteriima yang artinya Tindakan (Action) berpengaruh terhadap kepuasan pasien rawat jalan di RSUD Labuang Baji Makassar. Berdasarkan nilai $\mathrm{r}$ hitung diperoleh nilai 0,577 $>\mathrm{r}$ tabel 0,098 yang artinya terdapat hubungan yang kuat dan positif antara Tindakan (Action) terhadap kepuasan pasien. Dapat dijelaskan bahwa semakin baik Tindakan (Action) maka semakin tinggi kepuasan pasien rawat jalan di RSUD Labuang Baji Makassar.

Berdasarkan tabel 8 diperoleh informasi bahwa dari 385 responden yang menilai 
Reski Dewi Pratiwi, Ryryn Suryaman Prana Putra : Pengaruh Pelayanan Prima terhadap ...

Kemampuan (Ability) baik, sebagian besar merasa puas dengan pelayanan prima di rawat jalan RSUD Labuang Baji Makassar yakni sebanyak 372 orang (96,6\%). Dari 12 responden yang menilai Kemampuan (Ability) kurang baik, sebagian besar merasa puas dengan pelayanan prima di rawat jalan RSUD Labuang Baji Makassar yakni sebanyak 8 orang (66,7\%). Berdasarkan uji chi square diperoleh nilai $P$ sebesar 0,001 yang lebih kecil dari nilai $\alpha=0,05$ sehingga Ho ditolak dan Ha diteriima yang artinya Kemampuan (Ability) berpengaruh terhadap kepuasan pasien rawat jalan di RSUD Labuang Baji Makassar. Berdasarkan nilai $\mathrm{r}$ hitung diperoleh nilai 0,595 > r tabel 0,098 yang artinya terdapat hubungan yang kuat dan positif antara Kemampuan (Ability) terhadap kepuasan pasien. Dapat dijelaskan bahwa semakin baik Kemampuan (Ability) maka semakin tinggi kepuasan pasien rawat jalan di RSUD Labuang Baji Makassar.

Berdasarkan tabel 8 diperoleh informasi bahwa dari 382 responden yang menilai Penampilan (Appearance) baik, sebagian besar merasa puas dengan pelayanan prima di rawat jalan RSUD Labuang Baji Makassar yakni sebanyak 371 orang (97,1\%). Dari 15 responden yang menilai Penampilan (Appearance) kurang baik, sebagian besar merasa puas dengan pelayanan prima di rawat jalan RSUD Labuang Baji Makassar yakni sebanyak 9 orang (60,0\%). Berdasarkan uji chi square diperoleh nilai $P$ sebesar 0,000 yang lebih kecil dari nilai $\alpha=0,05$ sehingga Ho ditolak dan Ha diteriima yang artinya Penampilan (Appearance) berpengaruh terhadap kepuasan pasien rawat jalan di RSUD Labuang Baji Makassar. Berdasarkan nilai $r$ hitung diperoleh nilai 0,624 > r tabel 0,098 yang artinya terdapat hubungan yang kuat dan positif antara Penampilan (Appearance) terhadap kepuasan pasien. Dapat dijelaskan bahwa semakin baik Penampilan (Appearance) maka semakin tinggi kepuasan pasien rawat jalan di RSUD Labuang Baji Makassar.

Berdasarkan tabel 8 diperoleh informasi bahwa dari 375 responden yang menilai Tanggung Jawab (Accountability) baik, sebagian besar merasa puas dengan pelayanan prima di rawat jalan RSUD Labuang Baji Makassar yakni sebanyak 366 orang (97,6\%). Dari 22 responden yang menilai Tanggung Jawab (Accountability) kurang baik, sebagian besar merasa puas dengan pelayanan prima di rawat jalan RSUD Labuang Baji Makassar yakni sebanyak 14 orang (63,6\%). Berdasarkan uji chi square diperoleh nilai $P$ sebesar 0,000 yang lebih kecil dari nilai $\alpha=0,05$ sehingga Ho ditolak dan Ha diteriima yang artinya Tanggung Jawab (Accountability) berpengaruh terhadap kepuasan pasien rawat jalan di RSUD Labuang Baji Makassar. Berdasarkan nilai r hitung diperoleh nilai 0,673 > r tabel 0,098 yang artinya terdapat hubungan yang kuat dan positif antara Tanggung 
Jawab (Accountability) terhadap kepuasan pasien. Dapat dijelaskan bahwa semakin baik Tanggung Jawab (Accountability) maka semakin tinggi kepuasan pasien rawat jalan di RSUD Labuang Baji Makassar.

\section{PEMBAHASAN}

Pelayanan prima adalah pelayanan yang terbaik yang diberikan perusahaan untuk memenuhi harapan dan kebutuhan pelanggan, baik pelanggan di dalam perusahaan maupun di luar perusahaan (Daryanto \& Setyobudi, 2014). Pelayanan prima dalam penelitian ini dianalisis dengan variabel Sikap (Attitude), Perhatian (Attention), Tindakan (Action), Kemampuan (Ability,), Penampilan (Appearance), dan Tanggung iawab (Accountability) terhadap kepuasan pasien rawat jalan di RSUD Labuang Baji Makassar. Penelitian ini menganalisis pengaruh penerapan pelayanan prima terhadap kepuasan pasien rawat jalan di RSUD Labuang Baji Makassar.

Berdasarkan uji univariat pelayanan prima di RSUD Labuang Baji Makassar diperoleh hasil bahwa sebagian besar responden menilai Sikap (Attitude), Perhatian (Attention), Tindakan (Action), Kemampuan (Ability), Penampilan (Appearance), dan Tanggung Jawab (Accountability) dalam kategori baik. Sedangkan untuk variabel Kepuasan diperoleh hasil bahwa sebagian besar responden yakni pasien rawat jalan di RSUD Labuang Baji Makassar merasa puas dengan pelayanan prima di rumah sakit tersebut.

Sikap (Attitude) dalam penelitian ini adalah perilaku yang ditampilkan petugas kesehatan kepada pasien rawat jalan di RSUD Labuang Baji Makassar sebagai salah satu bagian pelayanan prima rumah sakit. Hasil penelitian diperoleh informasi bahwa sebagian besar responden menilai Sikap (Attitude) baik, namun dari yang menilai baik tersebut masih ada yang merasakan kurang puas terhadap pelayanan prima di rawat jalan RSUD Labuang Baji Makassar, dimana hal ini disebabkan berdasarkan persentase jawaban tiap pertanyaan pada variabel Sikap (Attitude) responden ada yang menilai kesabaran, keramahan, kesopanan, sapa dan senyum petugas kesehatan dalam kategori kurang baik sehingga mempengaruhi kepuasan pasien. Hasil uji chi square diperoleh kesimpulan bahwa Sikap (Attitude) berpengaruh terhadap kepuasan pasien rawat jalan di RSUD Labuang Baji Makassar, dimana artinya semakin baik Sikap (Attitude) petugas kesehatan maka semakin meningkatkan kepuasan pasien rawat jalan RSUD Labuang Baji Makassar. Hasil penelitian ini sejalan dengan penelitian Kelana (2015), yang menemukan bahwa ada pengaruh penerapan pelayanan prima perawat terhadap tingkat kepuasan pasien di Rumah 
Reski Dewi Pratiwi, Ryryn Suryaman Prana Putra : Pengaruh Pelayanan Prima terhadap ...

Sakit Universitas Tanjungpura Kota Pontianak. Penelitian ini juga sejalan dengan penelitian Sinollah (2020), yang menemukan bahwa sikap berpengaruh terhadap kepuasan konsumen di Rumah Sakit Amelia dan HVA Pare.

Perhatian (Attention) dalam penelitian ini adalah kepedulian petugas kesehatan yang terkait dengan perhatian akan kebutuhan dan keinginan pasien rawat jalan di RSUD Labuang Baji Makassar sebagai salah satu bagian pelayanan prima rumah sakit. Hasil penelitian diperoleh informasi bahwa sebagian besar responden menilai Perhatian (Attention) baik, namun dari yang menilai baik tersebut masih ada yang merasakan kurang puas terhadap pelayanan prima di rawat jalan RSUD Labuang Baji Makassar, dimana hal ini disebabkan berdasarkan persentase jawaban tiap pertanyaan pada variabel Perhatian (Attention) responden ada yang menilai petugas memenuhi kebutuhan pasien, informasi yang jelas dari petugas, bahasa yang baik, mudah dimengerti, akrab dengan pasien, perhatian terhadap keluhan pasien, menanyakan kabar dan keadaan pasien sebelum memulai pemeriksaan dalam kategori kurang baik sehingga mempengaruhi kepuasan pasien. Hasil uji chi square diperoleh kesimpulan bahwa Perhatian (Attention) berpengaruh terhadap kepuasan pasien rawat jalan di RSUD Labuang Baji Makassar, dimana artinya semakin baik Perhatian (Attention) petugas kesehatan maka semakin meningkatkan kepuasan pasien rawat jalan RSUD Labuang Baji Makassar. Hasil penelitian ini sejalan dengan penelitian Sinollah (2020), yang menemukan bahwa perhatian berpengaruh terhadap kepuasan konsumen di Rumah Sakit Amelia dan HVA Pare. Namun hasil penelitian ini tidak sejalan dengan penelitian Firdhousy (2016), yang menemukan bahwa faktor yang mempengaruhi implementasi pelayanan prima adalah komunikasi, sumber daya, disposisi, dan struktur birokrasi.

Tindakan (Action) dalam penelitian ini adalah semua kegiatan maksimal yang diberikan oleh petugas kesehatan kepada pasien rawat jalan di RSUD Labuang Baji Makassar. Hasil penelitian diperoleh informasi bahwa sebagian besar responden menilai Tindakan (Action) baik, namun dari yang menilai baik tersebut masih ada yang merasakan kurang puas terhadap pelayanan prima di rawat jalan RSUD Labuang Baji Makassar, dimana hal ini disebabkan berdasarkan persentase jawaban tiap pertanyaan pada variabel Tindakan (Action) responden ada yang menilai seperti respon petugas terhadap keluhan pasien kurang cepat, komunikasi dengan pasien, mendengarkan keluhan pasien dengan seksama, informasi yang lengkap dan jelas terkait penyembuhan pasien, serta waktu tunggu pasien dalam kategori kurang baik sehingga mempengaruhi kepuasan pasien. Hasil uji chi square diperoleh kesimpulan bahwa Tindakan (Action) berpengaruh 
terhadap kepuasan pasien rawat jalan di RSUD Labuang Baji Makassar, dimana artinya semakin baik Tindakan (Action) petugas kesehatan maka semakin meningkatkan kepuasan pasien rawat jalan RSUD Labuang Baji Makassar. Hasil penelitian ini sejalan dengan penelitian (Aini \& Nurdiana, 2017), yang menemukan bahwa ada hubungan antara pelayanan prima (Excellent Service) perawat dengan kepuasan pasien di ICU RSUD Syarifah Ambami Rato Ebu Bangkalan. Hasil penelitian ini juga sejalan dengan penelitian Sinollah (2020), yang menemukan bahwa tindakan berpengaruh terhadap kepuasan konsumen di Rumah Sakit Amelia dan HVA Pare.

Kemampuan (Ability) dalam penelitian ini adalah pengetahuan dan keterampilan petugas kesehatan kepada pasien dalam memberikan pelayanan prima kepada pasien rawat jalan di RSUD Labuang Baji Makassar. Hasil penelitian diperoleh informasi bahwa sebagian besar responden menilai Kemampuan (Ability) baik, namun dari yang menilai baik tersebut masih ada yang merasakan kurang puas terhadap pelayanan prima di rawat jalan RSUD Labuang Baji Makassar, dimana hal ini disebabkan berdasarkan persentase jawaban tiap pertanyaan pada variabel Kemampuan (Ability) responden ada yang menilai kesabaran petugas kesehatan menghadapi keluh kesah pasien, pelayanan yang cepat, tepat, dan tidak berbelit-belit, sungguh-sungguh dalam memeriksa pasien, penjelasan terkait dengan penyakit dan pengobatan yang akan dijalani pasien, serta petugas yang meminta persetujuan pasien sebelum dilakukan tindakan perawatan dalam kategori kurang baik sehingga mempengaruhi kepuasan pasien. Hasil uji chi square diperoleh kesimpulan bahwa Kemampuan (Ability) berpengaruh terhadap kepuasan pasien rawat jalan di RSUD Labuang Baji Makassar, dimana artinya semakin baik Kemampuan (Ability) petugas kesehatan maka semakin meningkatkan kepuasan pasien rawat jalan RSUD Labuang Baji Makassar. Hasil penelitian ini sejalan dengan penelitian Suasnawa \& Gorda (2017), yang menemukan bahwa pelayanan prima berpengaruh positif terhadap kepuasan pasien di Rumah Sakit Umum Bali Royal. Hasil penelitian ini juga sejalan dengan penelitian Sinollah (2020), yang menemukan bahwa kemampuan berpengaruh terhadap kepuasan konsumen di Rumah Sakit Amelia dan HVA Pare.

Penampilan (Appearance) dalam penelitian ini adalah penampilan petugas kesehatan yang ditampakkan kepada kepada pasien rawat jalan di RSUD Labuang Baji Makassar. Hasil penelitian diperoleh informasi bahwa sebagian besar responden menilai Penampilan (Appearance) baik, namun dari yang menilai baik tersebut masih ada yang merasakan kurang puas terhadap pelayanan prima di rawat jalan RSUD Labuang Baji Makassar, dimana hal ini disebabkan berdasarkan persentase jawaban tiap pertanyaan 
Reski Dewi Pratiwi, Ryryn Suryaman Prana Putra : Pengaruh Pelayanan Prima terhadap ...

pada variabel Penampilan (Appearance) responden ada yang menilai kerapihan dna kebersihan pakaian petugas kesehatan, penampilan menarik dan wangi, tutur kata yang tidak menyinggung perasaan pasien saat melakukan pelayanan, cara memperlakukan pasien, serta alat alat kesehatan yang digunakan petugas kesehatan dalam kategori kurang baik sehingga mempengaruhi kepuasan pasien. Hasil uji chi square diperoleh kesimpulan bahwa Penampilan (Appearance) berpengaruh terhadap kepuasan pasien rawat jalan di RSUD Labuang Baji Makassar, dimana artinya semakin baik Penampilan (Appearance) petugas kesehatan maka semakin meningkatkan kepuasan pasien rawat jalan RSUD Labuang Baji Makassar. Hasil penelitian ini sejalan dengan penelitian Sinollah (2020), yang menemukan bahwa penampilan berpengaruh terhadap kepuasan konsumen di Rumah Sakit Amelia dan HVA Pare.

Tanggung jawab (Accountability) dalam penelitian ini adalah bagaimana kesehatan dalam memberikan pelayanan tanpa membeda-bedakan pasien rawat jalan di RSUD Labuang Baji Makassar. Hasil penelitian diperoleh informasi bahwa sebagian besar responden menilai Tanggung jawab (Accountability) baik, namun dari yang menilai baik tersebut masih ada yang merasakan kurang puas terhadap pelayanan prima di rawat jalan RSUD Labuang Baji Makassar, dimana hal ini disebabkan berdasarkan persentase jawaban tiap pertanyaan pada variabel Tanggung jawab (Accountability) responden ada yang menilai petugas kesehatan tepat waktu dan tidak terlambat memberikan pelayanan, petugas menjawab pertanyaan pasien dengan jelas dan penuh keyakinan, selalu menggunakan alat pelindung (masker, sarung tangan, dan lain-lain), hati-hati dalam melakukan setiap tindakan pemeriksaan dan perawatan, serta memberikan rasa aman kepada pasien ketika berobat dalam kategori kurang baik sehingga mempengaruhi kepuasan pasien. Hasil uji chi square diperoleh kesimpulan bahwa Tanggung jawab (Accountability) berpengaruh terhadap kepuasan pasien rawat jalan di RSUD Labuang Baji Makassar, dimana artinya semakin baik Tanggung jawab (Accountability) petugas kesehatan maka semakin meningkatkan kepuasan pasien rawat jalan RSUD Labuang Baji Makassar. Hasil penelitian ini sejalan dengan penelitian Sinollah (2020), yang menemukan bahwa tanggung jawab berpengaruh terhadap kepuasan konsumen di Rumah Sakit Amelia dan HVA Pare. Hasil penelitian ini juga sejalan dengan penelitian Suasnawa \& Gorda (2017), yang menemukan bahwa pelayanan prima berpengaruh positif terhadap kepuasan pasien di Rumah Sakit Umum Bali Royal. 


\section{SIMPULAN}

Terdapat pengaruh pelayanan prima dari variabel Sikap (Attitude) dengan nilai $\mathrm{p}=0,007$, Perhatian (Attention) dengan nilai $\mathrm{p}=0,001$, Tindakan (Action) dengan nilai $\mathrm{p}=0,003$, Kemampuan (Ability) dengan nilai $\mathrm{p}=0,001$, Penampilan (Appearance) dengan nilai $\mathrm{p}=0,000$, dan Tanggung Jawab (Accountability) dengan nilai $\mathrm{p}=0,000$ terhadap kepuasan pasien rawat jalan di RSUD Labuang Baji Makassar. Diharapkan kepada pihak RSUD Labuang Baji Makassar untuk memperhatikan dan mempertahankan item variabel Sikap (Attitude), Perhatian (Attention), Tindakan (Action), Kemampuan (Ability), Penampilan (Appearance), dan Tanggung Jawab (Accountability) karena terbukti secara signifikan variable-variabel tersebut mempengaruhi kepuasan pasien di ruang rawat jalan RSUD Labuang Baji Makassar.

\section{UCAPAN TERIMA KASIH}

Penulis mengucapkan terima kasih yang sebesar-besarnya kepada Kementerian Riset dan Teknologi/ Badan Riset dan Inovasi Nasional Deputi Bidang Penguatan Riset dan Pengembangan Republik Indonesia yang telah memberikan bantuan dana dan dukungan, RSUD Labuang Baji Makassar yang telah memberikan ijin pelaksanaan dan dukungan selama dalam melaksanakan penelitian, serta kepada LPPM dan civitas kampus Stikes Pelamonia Makassar yang telah memberikan informasi dan dukungan terkait pelaksanaan penelitian ini.

\section{DAFTAR PUSTAKA}

Ahmed, J. S., \& Ilyas, F. (2016). Quality and Satisfaction in Healthcare Sector of Pakistan- “The Patient's Expectations.” https://doi.org/10.1108/IJHCQA08-2016-0110

Aiken, L. H., Sloane, D. M., Ball, J., Bruyneel, L., Rafferty, A. M., \& Griffiths, P. (2018). Patient Satisfaction with Hospital Care and Nurses in England: An Observational Study. BMJ Open, 8(1), 1-8. https://doi.org/10.1136/bmjopen2017-019189

Aini, Q., \& Nurdiana, A. (2017). Hubungan Pelayanan Prima (Excellent Service) Perawat Dengan Kepuasan Pasien Di Intensive Care Unit RSUD Syamrabu Bangkalan. Sekolah Tinggi Ilmu Kesehatan (STIKes) Ngudia Husada Madura.

Daryanto, \& Setyobudi. (2014). Konsumen dan Pelayanan Prima. Gava Media.

Endarini, S. (2001). Pelayanan Prima Makalah (tidak diterbitkan). Yogyakarta: Kanwil Departemen Kesehatan Propinsi DIY

Firdhousy, Z. (2016). Implementasi Pelayanan Prima bagi Pasien Rawat Inap Jaminan Kesehatan Nasional (JKN) Penerima Bantuan Iuran (PBI) di RSUP Dr Sarjito Yogyakarta. Fakultas Dakwan dan Komunikasi Universitas Islam Negeri Sunan Kalijaga Yogyakarta.

Hadjam, Noor Rochman. (2001). Efektivitas Pelayanan Prima sebagai Upaya MeningkatkanPelayanan di Rumah Sakit (Perspektif Psikologi). Jurnal Psikologi, 2, 105-115 
Kelana, M. T. (2015). Pengaruh Penerapan Pelayanan Prima (Service Excellence) Perawat Terhadap Tingkat Kepuasan Pasien Di Rumah Sakit Universitas Tanjungpura Kota Pontianak. Naskah Publikasi Prodi Keperawatan Fakultas Kedokteran Universitas Tanjungpura Pontianak.

Mamik. (2010). Organisasi dan Manajemen Pelayanan Kesehatan dan Kebidanan (1st ed.). Prins Media Publishing.

Nurcahyati, E., \& Setiawan, H. (2017). Studi Hubungan antara Mutu Pelayanan Kesehatan dengan Kepuasan Pasien di Unit Pelayanan Rawat Inap Rumah Sakit Umum Daerah Bhakti Dharma Husada Kota Surabaya. Jurnal Manajemen Kesehatan Yayasan RS. Dr. Soetomo, 3(1), 15-30.

Nursalam. (2014). Manajemen Keperawatan (Aplikasi dalam Praktik Keperawatan Profesional) (4th ed.). Salemba Medika.

Nursalam. (2015). Manajemen Keperawatan (Aplikasi dalam Praktik Keperawatan Profesional) (5th ed.). Salemba Medika.

Putri Parasuraman, A. Valerie, (2001). Delivering Quality Service (Diterjemahkan oleh Sutanto). The Free Press, New York.

Putri, R. A. (2016). Faktor-faktor yang Berhubungan dengan Pelayanan Prima Pegawai Rawat Jalan Puskesmas Kecamatan Kebon Jeruk Jakarta Barat Tahun 2015. http://repository.uinjkt.ac.id/dspace/handle/123456789/29640

Rivai, Pasinringi, Noor, Arifah, \& Mangilep. (2019). Peningkatan Pengetahuan Karyawan Rumah Sakit Umum DaerahLabuang Baji Makassar Pasca Pelatihan Pelayanan Prima RSUD Labuang Baji Makassar. TEPAT Jurnal Teknologi Terapan untuk Pengabdian Masyarakat | Volume 2, Nomor 1, Tahun 2019.

Shakya, N. R., \& Shakya, B. (2019). Patient Satisfaction with Outpatient Physiotherapy Services in Dhulikhel Hospital, Kathmandu University Hospital, Nepal. Kathmandu University Medical Journal, 17(65), 46-50.

Sinollah. (2020). Service Excellent Rumah Sakit Amalia dan HVA Pare, Kediri. Dialektika Jurnal Iilmu Ekonomi Dan Ilmu Sosial, 5(September). https://doi.org/10.36636/dialektika.v5i2.460

Suasnawa, I. G., \& Gorda, A. A. N. E. S. (2017). Pengaruh Pelayanan Prima dan Customer Relationship Management terhadap Loyalitas Pasien yang dimediasi oleh Kepuasan dan Kepercayaan. Jurnal Manajemen Dan Bisnis, 14(1), 56-74. http://journal.undiknas.ac.id/index.php/magister-manajemen/

Wijaya, S., \& Adriansyah, A. A. (2020). Efektivitas Pelaksanaan Marketing Mix 9P terhadap Kepuasan Pelayanan Klinik Rawat Jalan Rumah Sakit Jemursari Surabaya. Jurnal Manajemen Kesehatan Yayasan RS. Dr. Soetomo, 6(1), 2842.

\begin{tabular}{|l|l|}
\hline Submission & 11 November 2020 \\
\hline Review & 11 Januari - 24 Maret 2021 \\
\hline Accepted & 25 Maret 2021 \\
\hline Publish & 12 April 2021 \\
\hline DOI & 10.29241/jmk.v7i1.587 \\
\hline Sinta Level & Tiga (3) Nasional Akreditasi \\
\hline
\end{tabular}

